\title{
Powder Puff Chinese Crested
}

National Cancer Institute

\section{Source}

National Cancer Institute. Powder Puff Chinese Crested. NCI Thesaurus. Code C53949.

The Powder Puff Chinese Crested is a long-haired variety of the Chinese crested breed.

Height: 12 inches (30 cm.) Weight: not over 10 pounds (4.5 kg.) 